\title{
Identifying the performance drivers of wastewater treatment plants through conditional order-m efficiency analysis
}

\author{
Guerrini Andrea $^{a *}$, Romano Giulia ${ }^{b}$, Mancuso Fabrizio ${ }^{c}$, Carosi Laura ${ }^{b}$ \\ ${ }^{\text {a }}$ University of Verona, Department of Business Administration, Via dell'Artigliere 19, 37129 \\ Verona, Italy \\ ${ }^{\mathrm{b}}$ University of Pisa, Department of Economics and Management, Via Cosimo Ridolfi 10, 56124 \\ Pisa, Italy \\ c Ingegnerie Toscane, R\&D Area, Via Bellatalla 1, 56121 Ospedaletto (Pisa), Italy \\ *Corresponding author. Email: andrea.guerrini@univr.it
}

\begin{abstract}
European water utilities have to comply with environmental laws and, at the same time, should control costs in order to restrain tariff growth and earn profits. By applying a conditional order-m efficiency method, this study provides some insights to the operational variables affecting the efficiency of 137 wastewater treatment plants. These performance drivers are categorized as: 1) wastewater features, 2) plant technology, 3) other plant features, 4) output quality, and 5) sludge disposal method. Starting from prior literature, this paper provides some useful insights on the best policies that could be adopted by a utility to catch cost savings.
\end{abstract}

\section{Introduction}

Wastewater collected from municipalities and communities must be treated to remove pollutants. Wastewater treatment is the process of purifying water, removing some or all of the contaminants, and making it fit for reuse or discharge to surface water bodies such as rivers or oceans, or to groundwater. Alternatively, treated wastewater can be reused. Wastewater treatment is the final process in the cycle of water services, and two main challenges to this activity still exist: increasing the environmental sustainability of the process and minimizing the economic cost of operating this service, given that expenditure on wastewater management and treatment in the European Union with 28 member states was around $0.60 \%$ of GDP (Eurostat 2013). 
Some of the environmental problems of wastewater collection and treatment involve renewing aging sewer systems and upgrading wastewater treatment plants. These might include repair and replacement of leaking and undersized sewers, and upgrading treatment systems to achieve higher levels of removal for specific constituents. The European Union (EU) has begun several infringement proceedings against Italy, as it is not meeting the deadlines for the transposition of EU directive 271/91 for wastewater, and the terms of adoption have long expired. In 2012, the European Commission took Italy to the EU Court of Justice for its failure to ensure a proper treatment of wastewater from agglomerations with more than 10,000 inhabitants discharging into sensitive areas. In 2011, the Commission informed Italy that more than 143 towns were still not connected to a suitable sewage system and/or lacked secondary treatment facilities or had insufficient treatment capacity.

The process of renewing infrastructure to comply with EU directive $271 / 91$ is resulting in increased investment and greater cost of wastewater treatment being charged to customers through tariffs. In 2013, an Italian household paid $197 €$ for consumption of $150 \mathrm{~m}^{3}$ on average, consisting of $42 \%$ for water supply, $28 \%$ for wastewater treatment, and $13 \%$ for sewerage (Federconsumatori, 2014). Even in other developed European countries, the weight of wastewater transport and treatment is high: e.g., in Denmark $43 \%$ is paid to treat sewage, $30 \%$ for drinking water, and $26 \%$ for water transport (Danva Report, 2013); similarly in Germany, 58\% of the tariff is for sewage disposal (BDEW, 2010). This implies that water utilities must apply effective management control to their treatment process in order to keep costs low and to improve efficiency.

The literature on the economics of water services has mainly analyzed the overall efficiency of utilities, without distinguishing among water supply, sewerage services, and wastewater treatment (Abbott et al., 2011; Ashton, 2000; da Cruz et al., 2012; Guerrini et al., 2013; Guerrini and Romano, 2014; Romano and Guerrini, 2011; Saal and Parker, 2001). A second stream of research has focused on single segments, such as water supply and/or wastewater transport and treatment (Knapp, 1978; Rossi et al., 1979; da Cruz et al., 2013; Guerrini et al., 2015). More recently, a third field of study has 
been developed, based on the performance management of specific sub-processes of water services. Beginning with the pioneering work of Hsiao and Yang (2007), several scholars have studied the efficiency of wastewater treatment plants and their determinants.

We follow the approach of this last stream of research, measuring the efficiency of 137 Wastewater Treatment Plants (WWTPs) managed by an Italian water utility in the Tuscany region. Adopting a conditional order-m, this paper aims to identify those performance drivers affecting the plant's efficiency, analyzing a list of 12 operational variables that can be clustered as wastewater features, WWTP technology, other features of WWTPs, output quality, and methods of sludge disposal.

Since prior literature on WWTP efficiency provided some controversial results and is based on a restricted number of variables, the main contribution of this article is that it is based on a greater number of explanatory variables that could potentially affect efficiency, and it helps to better understand the effect exerted by certain exogenous factors.

This article is organized in the following manner. After this introduction, Section 2 describes the characteristics of a process for wastewater treatment; Section 3 describes the main evidence obtained from up-to-date studies of WWTP performance, and lists all the collected variables and drivers that seem to influence efficiency. Section 4 presents the conditional order-m model and the data used, consisting of 137 observations for 23 selected variables for the year 2014. Section 5 summarizes and discusses the obtained results, and Section 6 concludes the paper.

\section{The process of wastewater treatment}

Wastewater may be defined as a combination of liquid or water-borne wastes removed from residences, institutions, and commercial and industrial establishments, together with such groundwater, surface water, and storm water as may be present.

Wastewater is transported underground through sewers to treatment or disposal facilities. Older sewer systems (combined sewers) were designed to carry both sewage and surface runoff, whereas 
modern sewer systems are designed either to convey wastewater (sanitary sewers) or to drain surface runoff (storm sewers), and to keep these separate (Masotti, 2011).

The important constituents of concern in wastewater treatment are shown in Table 1. Wastewater treatment methods are chosen according to the environmental standards that must be achieved to ensure protection of public health and the environment, in relation to state and local regulations.

Methods of treatment in which the application of physical forces predominate are known as unit operations; methods of treatment in which the removal of contaminants is brought about by chemical or biological reactions are known as unit processes. The most commonly used unit operations and processes are also shown in Table 1, with respect to the constituents to be removed during the wastewater treatment.

Unit operations and processes are combined and arranged to provide various levels of treatment known as preliminary, primary, advanced primary, secondary (without or with nutrient removal), and tertiary (advanced) treatment. In preliminary treatment, gross solids such as large objects, rags, and grit are removed to prevent damage to equipment. In primary treatment, a physical operation (usually sedimentation) is used to remove the floating and settable materials found in wastewater. For advanced primary treatment, chemicals are added to enhance removal of suspended solids and, to a lesser extent, dissolved solids. In secondary treatment, biological and chemical processes are used to remove most of the organic matter. In tertiary treatment, additional combinations of unit operations and processes are used to remove residual suspended solids and other constituents that are not reduced significantly by conventional secondary treatment.

Secondary treatment standards for wastewater are not only concerned with the removal of biodegradable organics, total suspended solids, and pathogens, but also with the removal of nutrients, heavy metals, and priority pollutants (Bonomo, 2008).

Wastewater collected from municipalities and communities must ultimately be returned to receiving waters or to the land, or reused. In the case of wastewater reuse, standards normally include 
additional requirements for the removal of refractory organic, heavy metals, and in some cases, dissolved inorganic solids.

\section{Table 1}

Principal constituents of wastewater with the unit operations and processes used to remove them (Metcalf and Eddy, 2003)

\begin{tabular}{|c|c|c|}
\hline Constituent & Potential environmental risks & Unit operation or process \\
\hline Suspended solids & $\begin{array}{l}\text { Suspended solids can lead to the development of sludge deposits } \\
\text { and anaerobic conditions when untreated wastewater is } \\
\text { discharged in the aquatic environment. }\end{array}$ & $\begin{array}{l}\text { Screening } \\
\text { Grit removal } \\
\text { Sedimentation } \\
\text { High-rate clarification } \\
\text { Chemical precipitation } \\
\text { Flotation }\end{array}$ \\
\hline $\begin{array}{l}\text { Biodegradable } \\
\text { organics }\end{array}$ & $\begin{array}{l}\text { Biodegradable organics are measured most commonly in terms } \\
\text { of BOD (biochemical oxygen demand) and COD (chemical } \\
\text { oxygen demand). If discharged untreated to the environment, } \\
\text { their biological stabilization can lead to the depletion of natural } \\
\text { oxygen resources and to the development of septic conditions. }\end{array}$ & $\begin{array}{l}\text { Aerobic suspended growth variations } \\
\text { Aerobic attached growth variations } \\
\text { Anaerobic suspended growth variations } \\
\text { Anaerobic attached growth variations } \\
\text { Physical-chemical systems } \\
\text { Chemical oxidation } \\
\text { Advanced oxidation } \\
\text { Membrane filtration }\end{array}$ \\
\hline Pathogens & $\begin{array}{l}\text { Communicable diseases can be transmitted by pathogenic } \\
\text { organisms that may be present in wastewater. }\end{array}$ & $\begin{array}{l}\text { Chlorine compounds } \\
\text { Ozone } \\
\text { Ultraviolet (UV) radiation }\end{array}$ \\
\hline Nutrients & $\begin{array}{l}\text { Both nitrogen }(\mathrm{N}) \text { and phosphorus }(\mathrm{P}) \text {, along with carbon }(\mathrm{C}) \text {, are } \\
\text { essential nutrients for growth. When discharged to the aquatic } \\
\text { environment, these nutrients can lead to the growth of } \\
\text { undesirable aquatic life. When discharged in excessive amounts } \\
\text { on land, they can also lead to the pollution of groundwater. }\end{array}$ & $\begin{array}{l}\text { Nitrogen }(\mathrm{N}) \text { : } \\
\text { - } \quad \begin{array}{l}\text { Suspended growth nitrification and } \\
\text { denitrification variations }\end{array} \\
\text { - } \quad \begin{array}{l}\text { Attached growth nitrification and } \\
\text { denitrification variations }\end{array} \\
\text { Phosphorus (P): } \\
\text { - Chemical treatment } \\
\text { - Biological phosphorus removal } \\
\text { Nitrogen and Phosphorus (N-P): } \\
\\
\text { - Biological nutrient removal variations }\end{array}$ \\
\hline
\end{tabular}

The solids and biosolids (formerly collectively called sludge) resulting from wastewater treatment operations and processes are usually in the form of a liquid or semisolid liquid, depending on the operations and processes used. The term biosolids reflects the fact that wastewater solids are organic products that can be used beneficially after treatment with processes such as stabilization and composting. The term sludge is used only before beneficial use criteria have been achieved; this term 
is generally used in conjunction with a process descriptor, such as primary sludge, waste-activated sludge, and secondary sludge. Of the constituents removed by treatment, solids and biosolids are by far the largest in volume. Thickening (concentration), conditioning, dewatering, and drying are used primarily to remove moisture from solids, whereas digestion, composting, and incineration are used primarily to treat or stabilize organic material in solids.

Some of the problems of wastewater collection and treatment infrastructure deal with renewal of aging sewer systems and upgrading wastewater treatment plants. These might include repair and replacement of leaking and undersized sewers, and upgrading treatment systems to achieve higher levels of removal for specific constituents.

Portions of the collection systems are often older than the treatment plants. Substantial leakage is common because of the age of many of the pipes and ancillary structures, the types of materials and methods used in construction, and lack of repair.

Leakage occurs in the form of infiltration and inflow (liquids entering the collection system), and exfiltration (liquids leaving the system before arriving at their intended destination). In the former case, extraneous water has to be collected and treated, and may often overflow before treatment, especially during wet weather. In the latter case, exfiltration causes untreated wastewater to enter the groundwater and/or migrate to nearby surface water bodies.

\section{Evidence from prior studies}

Among the great variety of studies observing the efficiency of WWTPs from a technical and engineering point of view, only a few deal with this issue from a managerial and economic perspective. This section provides an overview of this sub-cluster of works, in order to identify the method adopted, in terms of tools for measuring efficiency and the variables collected, and the explanatory variables identified as efficiency drivers. Table 2 provides a summary of these issues, with further details (country, number of plants selected, input and output variables). 
First, the existing studies on WWTP efficiency are limited to specific geographic areas: Spain (Lorenzo-Toja et al., 2015) and, in particular, the Valencia and Catalonia regions (e.g., HernándezSancho and Sala-Garrido, 2009; Hernández-Sancho et al., 2011a, 2011b; Molinos-Senante et al., 2014a, 2014b, 2015; Sala-Garrido et al., 2011, 2012; Fuentes et al., 2015). Only two do not involve the Iberian Peninsula: Hsiao et al., (2007) in Taiwan and Frequelli and Giandrone (2003) in Italy. This demonstrates that Spanish academies and institutions have paid particular attention to these issues, which are not well-developed in other parts of the world, despite their relevance to the efficiency of water utilities.

From a methodological point of view, 10 of the 12 studies are based on non-parametric methods for efficiency measurement as Data Envelopment Analysis (DEA). Among these, seven articles combine DEA with non-parametric tests (Mann Mann-Whitney U test, Kruskal-Wallis test) or with a life cycle assessment (LCA) in order to develop a two-stage analysis for identifying the effects of specific exogenous variables on efficiency. Recently, Fuentes et al. (2015) performed a conditional order-m efficiency, according to the method developed by Daraio and Simar (2007). This model uses environmental variables to identify the most similar observations, and then uses them to estimate efficiency parameters, avoiding the limitations of other two-stage approaches. Only one study (Frequelli and Giandrone, 2003) applied a parametric method, based on a cost function model.

With an input-oriented DEA model, efficiency is measured by relating the consumption of input needed to obtain a given amount of output. In contrast, with an output-oriented model, the most efficient unit produces the highest amount of output consuming a given volume of input. The literature on WWTP efficiency is quite uniform when selecting the input/output variables, even if there are some interesting exceptions. Cost items are always selected as input, and the majority of studies detail several cost items, distinguishing among energy, staff, maintenance, waste management, and other costs. Others include only the total costs (Molinos-Senante et al., 2014b) or operating and maintenance costs (Molinos-Senante et al., 2015; Sala Garrido et al., 2011). Hsiao and Yang (2007) also measured the amount of investments realized by each plant. For output, two 
approaches are followed. The majority of the selected studies consider as output the difference between the pollution level in the influents and effluents (Net Environmental Benefits), or measure the quantity of pollutants removed. Other studies refer to the wastewater segments (sewer and treatment) or to the whole water utility, considering the volume of wastewater treated and/or population served (Picazo-Tadeo et al., 2009; da Cruz et al., 2013; De Witte and Marques, 2012).

Exogenous variables are operational and environmental factors affecting WWTP efficiency. Examining evidence from prior literature, these variables can be grouped into three main clusters:

i) wastewater features, represented by the pollution concentration; ii) WWTP technology, distinguishing between wastewater treatment technology (as activated sludge, extended aeration, trickling filter, biodisk, peat bed, type of aeration) and sludge treatment (such as anaerobic digestion, solar drying, mechanical dewatering); iii) other plant features, such as size, measured in terms of $\mathrm{m}^{3}$ of wastewater treated, capacity, measured with persons equivalent (PE), age, firms' vertical integration, and skill of operators.

The evidence from prior literature is consistent when examining some variables, such as size and plant capacity, which positively affect efficiency. This demonstrates the increasing return to scale, since the WWTP's outputs grow at a higher percentage than the inputs, which in turn allow average costs to decrease, yielding economies of scale. This occurs because a large operator has greater contractual power with suppliers when purchasing materials and services, and it can assign fixed costs to a higher volume of water treated, allowing the reduction of the actual unit cost.

For other variables, the results are quite conflicting. In some cases, the plant's age seems to exert a negative effect on efficiency, as demonstrated by Fuentes et al. (2015) and Molinos-Senante et al. (2014b). The negative effect of a plant's age can be ascribed to the poor performance of old plants. However, according to other studies, this exogenous variable does not affect performance (Hernández-Sancho et al., 2011a, 2011b).

The studies that observe the performance of different technologies consistently show the dominance of activated sludge and anaerobic digestion, but conflicting evidence arises when the 
effects of aeration systems are observed (Hernández-Sancho et al., 2011a; Fuentes et al., 2015). The greatest efficiency in anaerobic digestion is given by the production of biogas, which is used to generate energy. Activated sludge provides high flexibility to the plant with respect to organic load and amount of wastewater inflows. Furthermore, the internal recirculation increases the efficiency of nitrogen removal and facilitates the elimination of phosphorus. Finally, activated sludge is a technology adopted for a long period by water utilities that have mature relevant learning economies.

Finally, the pollution concentration of input wastewater has a negative effect, according to Fraquelli and Giandrone (2003) and Lorenzo-Toja et al. (2015). This can be explained by the higher costs incurred to remove an intense pollutant load, although other scholars have demonstrated the opposite effect (Fuentes et al., 2015), probably because of the larger amount of pollutants that can be removed from a cubic meter of concentrated wastewater than from a more diluted one.

Table 2. Evidence from prior studies.

\begin{tabular}{|c|c|c|c|c|c|c|c|c|}
\hline Article & Country & Sample & Input & Output & Method & \multicolumn{3}{|c|}{ Results } \\
\hline & & & & & & $\begin{array}{l}\text { Wastewater } \\
\text { features }\end{array}$ & $\begin{array}{c}\text { WWTP } \\
\text { technology }\end{array}$ & $\begin{array}{c}\text { Other features of } \\
\text { WWTP }\end{array}$ \\
\hline $\begin{array}{l}\text { Fraquelli } \\
\text { Giandrone } \\
(2003)\end{array}$ & Italy & $\begin{array}{l}103 \text { WWTPs } \\
\text { serving more } \\
\text { than } 10,000 \\
\mathrm{AE}\end{array}$ & Costs & $\begin{array}{l}\text { Volume } \\
\text { treated, } \\
\text { quality } \\
\text { characteristics }\end{array}$ & $\begin{array}{l}\text { Cost } \\
\text { function }\end{array}$ & $\begin{array}{l}\text { Pollution } \\
\text { concentration of } \\
\text { input wastewater } \\
\downarrow\end{array}$ & & $\begin{array}{l}\text { Plant capacity } \uparrow . \\
\text { Vertical integration } \uparrow\end{array}$ \\
\hline $\begin{array}{l}\text { Fuentes et } \\
\text { al. (2015) }\end{array}$ & Spain & $\begin{array}{l}158 \text { WWTPs } \\
\text { with } \\
\text { secondary } \\
\text { treatment }\end{array}$ & $\begin{array}{l}\text { Cost for } \\
\text { energy, staff, } \\
\text { and other } \\
\text { costs }\end{array}$ & $\begin{array}{l}\mathrm{SS}, \mathrm{COD} \\
\text { removed }\end{array}$ & $\begin{array}{l}\text { Conditional } \\
\text { order-m } \\
\text { efficiency }\end{array}$ & $\begin{array}{l}\text { Pollution } \\
\text { concentration of } \\
\text { input wastewater } \\
\uparrow\end{array}$ & $\begin{array}{l}\text { Type of } \\
\text { aeration } \leftrightarrow\end{array}$ & Size $\downarrow ;$ Age $\downarrow$ \\
\hline $\begin{array}{l}\text { Hernández- } \\
\text { Sancho and } \\
\text { Sala- } \\
\text { Garrido } \\
\text { (2009) }\end{array}$ & Spain & $\begin{array}{l}338 \text { WWTPs } \\
\text { with } \\
\text { secondary } \\
\text { treatment }\end{array}$ & $\begin{array}{l}\text { Cost for } \\
\text { energy, staff } \\
\text { maintenance } \\
\text {, and other } \\
\text { costs }\end{array}$ & $\begin{array}{l}\text { BOD5, COD, } \\
\text { SS removed }\end{array}$ & $\begin{array}{l}\text { DEA two } \\
\text { stage } \\
\text { (Kruskal- } \\
\text { Wallis test in } \\
\text { the } 2 \text { nd } \\
\text { stage) }\end{array}$ & & & Size $\uparrow$ \\
\hline $\begin{array}{l}\text { Hernández- } \\
\text { Sancho et } \\
\text { al. (2011a) }\end{array}$ & Spain & $\begin{array}{l}177 \text { WWTPs } \\
\text { with the same } \\
\text { technology }\end{array}$ & $\begin{array}{l}\text { Costs for } \\
\text { energy, staff, } \\
\text { reagents, }\end{array}$ & $\begin{array}{l}\mathrm{COD}, \mathrm{SS} \\
\text { removed }\end{array}$ & $\begin{array}{l}\text { Two stage } \\
\text { non radial } \\
\text { DEA }\end{array}$ & $\begin{array}{l}\text { Pollutants } \\
\text { removed } \uparrow\end{array}$ & $\begin{array}{l}\text { Type of } \\
\text { aeration } \\
\text { affects }\end{array}$ & Size $\uparrow ;$ Age $\leftrightarrow$ \\
\hline
\end{tabular}




\begin{tabular}{|c|c|c|c|c|c|c|c|c|}
\hline & & & \begin{tabular}{|l} 
maintenance, \\
waste \\
management, \\
and other \\
costs.
\end{tabular} & & & & $\begin{array}{l}\text { efficiency: } \\
\text { diffusers } \uparrow \\
\text { (are better } \\
\text { than turbines). }\end{array}$ & \\
\hline $\begin{array}{l}\text { Hernández- } \\
\text { Sancho et } \\
\text { al. (2011b) }\end{array}$ & Spain & $\begin{array}{l}196 \text { WWTPs } \\
\text { with } \\
\text { secondary } \\
\text { treatment }\end{array}$ & $\begin{array}{l}\text { Costs for } \\
\text { energy, staff, } \\
\text { reagents, } \\
\text { maintenance, } \\
\text { waste } \\
\text { management }\end{array}$ & $\begin{array}{l}\text { COD, SS } \\
\text { removed }\end{array}$ & $\begin{array}{l}\text { Malmquist } \\
\text { Productivity } \\
\text { Index and } \\
\text { Kruskal } \\
\text { Wallis in the } \\
\text { second stage }\end{array}$ & & $\begin{array}{l}\text { Biodisk } \\
\text { technology } \uparrow ; \\
\text { Peat bed } \\
\text { technology } \downarrow\end{array}$ & Size $\uparrow ;$ Age $\leftrightarrow$ \\
\hline $\begin{array}{l}\text { Hsiao \& } \\
\text { Yang } \\
(2007)\end{array}$ & Taiwan & 31 pig farms & $\begin{array}{l}\text { Investments, } \\
\text { O\&M costs, } \\
\text { work hours }\end{array}$ & $\begin{array}{l}\text { BOD5, COD, } \\
\text { SS removed }\end{array}$ & DEA & & & $\begin{array}{l}\text { Size } \uparrow \text {; Operator } \\
\text { skills }\end{array}$ \\
\hline $\begin{array}{l}\text { Lorenzo- } \\
\text { Toja et al. } \\
\text { (2015) }\end{array}$ & Spain & 113 WWTPs & $\begin{array}{l}\text { Cost for } \\
\text { energy, } \\
\text { reagents and } \\
\text { waste } \\
\text { management }\end{array}$ & $\begin{array}{l}\text { Net } \\
\text { Environmental } \\
\text { Benefits }\end{array}$ & LCA, DEA, & $\begin{array}{l}\text { Pollution } \\
\text { concentration of } \\
\text { input wastewater } \\
\downarrow\end{array}$ & $\begin{array}{l}\text { More complex } \\
\text { technology } \\
\text { and large } \\
\text { plants } \uparrow ; \\
\text { simpler } \\
\text { technology } \\
\text { and small } \\
\text { plants } \downarrow\end{array}$ & Size $\uparrow$ \\
\hline $\begin{array}{l}\text { Molinos- } \\
\text { Senante et } \\
\text { al. (2014a) }\end{array}$ & Spain & $\begin{array}{l}60 \text { WWTPs } \\
\text { mainly } \\
\text { receiving } \\
\text { urban } \\
\text { wastewater }\end{array}$ & Total costs & $\begin{array}{l}\mathrm{SS}, \mathrm{COD}, \mathrm{N} \text {, } \\
\mathrm{P} \text { removed } \\
\text { and } \mathrm{CO}_{2} \\
\text { emission as } \\
\text { undesirable } \\
\text { output }\end{array}$ & $\begin{array}{l}\text { DEA two } \\
\text { stage } \\
\text { (Kruskal- } \\
\text { Wallis test in } \\
\text { the 2nd } \\
\text { stage) }\end{array}$ & & $\begin{array}{l}\text { Anaerobic } \\
\text { digestion } \\
\uparrow(\text { better than } \\
\text { mechanical } \\
\text { dewatering } \\
\text { and aerobic } \\
\text { digestion) } \\
\end{array}$ & Size $\uparrow ;$ Age $\leftrightarrow$ \\
\hline $\begin{array}{l}\text { Molinos- } \\
\text { Senante et } \\
\text { al. (2014b) }\end{array}$ & Spain & $\begin{array}{l}192 \text { WWTPs } \\
\text { with } \\
\text { secondary } \\
\text { treatment }\end{array}$ & \begin{tabular}{|l} 
Costs for \\
energy, staff, \\
reagents, \\
maintenance, \\
waste \\
management, \\
other costs.
\end{tabular} & $\begin{array}{l}\text { COD, SS } \\
\text { removed }\end{array}$ & $\begin{array}{l}\text { Two stage } \\
\text { non radial } \\
\text { DEA } \\
\text { (Kruskal- } \\
\text { Wallis test in } \\
\text { the 2nd } \\
\text { stage) }\end{array}$ & & $\begin{array}{l}\text { Wastewater } \\
\text { treatment: } \\
\text { extended } \\
\text { aeration } \\
\text { technology } \uparrow ; \\
\text { biodisk } \\
\text { technology } \downarrow \text {; } \\
\text { peat bed } \downarrow \text {. } \\
\text { Sludge } \\
\text { treatment: } \\
\text { anaerobic } \\
\text { digestion } \uparrow ; \\
\text { solar drying } \downarrow \\
\end{array}$ & $\begin{array}{l}\text { Size } \uparrow \text {; Plant } \\
\text { capacity (PE) } \uparrow \text {; Age } \\
\downarrow\end{array}$ \\
\hline $\begin{array}{l}\text { Molinos- } \\
\text { Senante et } \\
\text { al. (2015) }\end{array}$ & Spain & $\begin{array}{l}99 \text { WWTPs } 4 \\
\text { alternative } \\
\text { technologies: } \\
\text { activated } \\
\text { sludge (AS), } \\
\text { aerated } \\
\text { lagoon (AL), } \\
\text { trickling filter } \\
\text { (TF) and } \\
\text { rotating } \\
\text { biological } \\
\text { contactor(BD) } \\
\end{array}$ & $\mathrm{O} \& \mathrm{M}$ costs & $\begin{array}{l}\mathrm{COD}, \mathrm{N}, \mathrm{P} \\
\text { removed }\end{array}$ & $\begin{array}{l}\text { Metafrontier } \\
\text { Malmquist } \\
\text { Productivity } \\
\text { Index }\end{array}$ & & $\begin{array}{l}\text { Activated } \\
\text { sludge } \uparrow ; \\
\text { rotating } \\
\text { biological } \\
\text { contactors } \uparrow\end{array}$ & \\
\hline $\begin{array}{l}\text { Sala- } \\
\text { Garrido et } \\
\text { al. (2011) }\end{array}$ & Spain & $\begin{array}{l}99 \text { WWTPs } \\
\text { with } \\
\text { secondary } \\
\text { treatment, but } \\
\text { with different } \\
\text { technologies }\end{array}$ & $O \& M$ costs & $\begin{array}{l}\text { COD, N, P } \\
\text { removed }\end{array}$ & $\begin{array}{l}\text { DEA } \\
\text { Metafrontier } \\
\text { approach and } \\
\text { technological } \\
\text { gap } \\
\text { ratios } \\
\text { (TGRs) } \\
\end{array}$ & & $\begin{array}{l}\text { Activated } \\
\text { sludge } \uparrow(\text { better } \\
\text { then aerated } \\
\text { lagoon, } \\
\text { trickling filter, } \\
\text { biodisk) }\end{array}$ & \\
\hline $\begin{array}{l}\text { Sala- } \\
\text { Garrido et } \\
\text { al. } 2012\end{array}$ & Spain & $\begin{array}{l}272 \text { WWTPs, } \\
\text { distinguishing } \\
\text { between those } \\
\text { with activated } \\
\text { sludge and } \\
\text { extended } \\
\text { aeration }\end{array}$ & $\begin{array}{l}\text { Costs for } \\
\text { energy, staff, } \\
\text { reagents, } \\
\text { maintenance, } \\
\text { waste } \\
\text { management, } \\
\text { and other } \\
\text { costs. }\end{array}$ & $\begin{array}{l}\mathrm{SS}, \mathrm{COD} \\
\text { removed }\end{array}$ & $\begin{array}{l}\text { DEA two } \\
\text { stage (Mann- } \\
\text { Whitney test } \\
\text { in the 2nd } \\
\text { stage) }\end{array}$ & & & $\begin{array}{l}\text { Non-seasonal } \\
\text { WWTPs } \uparrow \text { (effect of } \\
\text { seasonality on } \\
\text { energy costs). }\end{array}$ \\
\hline
\end{tabular}


From the evidence reported in Table 2, two relevant elements stand out. First, there are some controversial results that should be clarified by further research. Second, only some explanatory variables are considered in the current literature, and some aspects such as the method of sludge disposal, the output quality measured by the amount of discharged effluents, the percentage of working capacity, and the ratio among pollutants in wastewater inflows (as BOD5 to N and COD to BOD5) have not been investigated.

This study is intended to fill this gap in the literature by performing a conditional order-m efficiency analysis encompassing all the explanatory variables mentioned.

\section{Method and sample description}

\subsection{Choosing a method to measure the effect of exogenous variables on efficiency}

The measurement of the effect exerted by exogenous variables on the efficiency of Decision Making Units (DMU) is a matter of great relevance, since it gives the opportunity to better design strategies and to carry out effective control on performance and on its determinants. Furthermore, if the performance analyses are restricted to measuring the consumed inputs and outputs produced by each DMU without considering environmental and non-controllable factors, the results may indicate higher efficiencies for DMUs operating in a favorable environment, and low efficiencies for DMUs already affected by a harsh operational environment. For these two reasons, it is fundamental to isolate the effect exerted by exogenous variables on the efficiency, in order to identify the real capability of the management to purchase and combine input for output production.

Many studies have tried to address this issue through parametric and nonparametric approaches. Among non-parametric approaches, a widely used method is the DEA. However, this method has some flaws. The DEA two-stage approach has been criticized (Simar and Wilson, 2004, 2007) for failing to account for serial correlations in DEA scores. Because DEA scores may be biased, and the environmental variables correlated with output and input variables, bootstrapping techniques can 
better reveal the impact of environmental and operational variables on efficiency scores (e.g., Peda et al., 2013).

Furthermore, the classic two-stage method requires a restrictive separability condition between the input-output space and the environmental factors space. The separability condition means that the exogenous variables do not exert any effect on the frontier of the efficiency scores, but may influence only the distribution of the inefficiency scores (Badin et al., 2010; Badin et al., 2014). This could be a strong assumption if adopted in some case studies, where an external variable $\mathrm{Z}$ may affect both the frontier and/or the distribution of the inefficiencies. To overcome this last weakness, Daraio and Simar $(2005,2007)$ proposed a more suitable approach to investigate the influence of the operational environment on the efficiency of DMUs, which was also chosen in the current article. From the work of Cazals et al. (2002), the cited authors assumed that the production process can be considered as a set of random variables of $p$ inputs $(\mathrm{X})$ and $q$ outputs $(\mathrm{Y})$, so it can be described as a joint distribution function of inputs and outputs:

$H(x, y)=\operatorname{Prob}(X \leq x, Y \geq y)$

Constraining the production process to a given value of the environmental variable, it is possible to integrate the features of the operational environment $(Z)$ with the production process:

$$
H(x, y \mid z)=\operatorname{Prob}(X \leq x, Y \geq y \mid Z=z)
$$

This represents the probability of a DMU consuming $\mathrm{x}$ input and generating $\mathrm{y}$ output to be dominated by DMUs facing the same environmental conditions, z. From these distribution functions, conditional and unconditional efficiency scores can be obtained, and estimated using nonparametric methods (Daraio and Simar, 2007). Then, comparing these two efficiency measures, it is possible to show the influence exerted by environmental variables (e.g., Fuentes et al., 2015). The unconditional order-m input efficiency score for a DMU is estimated as follows (Daraio and Simar, 2007): 
$\hat{\theta}_{m, n}(x, y)=\int_{0}^{\infty}\left(1-\hat{F}_{X \mid Y, n}(u x \mid y)\right)^{m} d u$

where $\hat{F}_{X \mid Y, n}(u x \mid y)=\frac{\sum_{i=1}^{n} I\left(X_{i} \leq u x, Y_{i} \geq y\right)}{\sum_{i=1}^{n} I\left(Y_{i} \geq y\right)}$, and $I(k)$ is the indicator function that takes the value of $I(k)=1$ if $k$ is true, or $I(k)=0$ otherwise.

Meanwhile the conditional order-m efficiency scores can be estimated by the following (Daraio and Simar, 2007):

$\hat{\theta}_{m}(x, y \mid z)=\int_{0}^{\infty}\left(1-\hat{F}_{X \mid Y, Z, n}(u x \mid y, z)\right)^{m} d u$

where $\hat{F}_{X \mid Y, Z, n}(u x \mid y, z)=\frac{\sum_{i=1}^{n} I\left(X_{i} \leq u x, Y_{i} \geq y\right) K\left(\left(Z-Z_{i}\right) / h\right)}{\sum_{i=1}^{n} I\left(Y_{i} \geq y\right) K\left(\left(Z-Z_{i}\right) / h\right)}$

and $I$ is the univariate kernel functions, while $h$ is the appropriate bandwidth.

Then, having estimated the order-m conditional efficiency for each WWTP, the statistical significance of the contextual variables is studied. For this objective, the regression method developed by Racine and Li (2004) can be used:

$\hat{Q}_{i}^{z}=\tilde{f}\left(z_{i}\right)+\varepsilon_{i}, \quad i=1, \ldots, n$

where

$\hat{Q}_{i}^{z}=\frac{\hat{\theta}_{m, n}\left(x_{i}, y_{i} \mid z_{i}\right)}{\hat{\theta}_{m, n}\left(x_{i}, y_{i}\right)}$

is the ratio of conditional and unconditional efficiency.

In this research, the Epanechnikov kernel function was adopted for the continuous environmental variables, solving a weighted local polynomial smoothing, which is less affected by extreme observations. For categorical environmental variables, a lowess smoothing regression was adopted, 
which carries out a locally weighted regression of $\mathrm{y}$ on $\mathrm{x}$. The optimal bandwidth was obtained according to a data-driven technique proposed by Badin et al. (2010), and based on a least squares cross validation procedure.

When regressing the ratio of conditional over unconditional efficiencies nonparametrically, in an input orientation context, the environmental variable is unfavorable to efficiency when the nonparametric regression has a positive slope as the values of the environmental variable increase. This occurs because when the environmental variable improves efficiency, the conditional efficiencies tend to be higher than the unconditional efficiencies as the values of the environmental variable increase. The opposite occurs when the environmental variable is favorable to efficiency.

\subsection{Sample and model specification}

Our analysis involves 137 WWTPs in Tuscany that are controlled by Acque SpA, a public-private utility entrusted in 2002 with water services in the so-called "Basso Valdarno" river basin in the Pisa province. The data grid for this study was constructed with the support of the Tuscan water authority staff and the technical staff of Acque SpA. The data for year 2014 were gathered by a team of engineers from the water utility, and their consistency was double-checked by Acque management and researchers.

The model defined for efficiency estimation includes, as input variables, the total costs of collection (in euros), adding costs of reagents and materials, energy, staff, maintenance, depreciation, sludge transport and disposal, costs for other waste disposal, and general costs related to surveillance and administration. The output consists of the total amount of wastewater treated $\left(\mathrm{m}^{3}\right)$. The selected input is consistent with that in prior literature, since all scholars include cost among input variables. The choice to aggregate all cost items into a single cost value allows us to measure cost efficiency, since prices are the same across the observed DMUs, but it avoids any measurement of technical efficiency (Portela, 2014). In contrast, the chosen output is different from that selected by the mainstream literature, which often measures the quantity of pollutants removed in order to value the 
production of a plant. However, the volume of treated wastewater, used in this paper as output measure, is more consistent with the Italian tariff system, which states that wastewater services are paid by citizens according to the volume of drinkable water consumed. This input/output model allows the identification of the more efficient plants as those applying the lowest tariffs to citizens.

An input orientation was assumed, so that the WWTPs have to reduce their inputs (in this case, costs) to the level of outputs produced (cubic meter of wastewater treated). Table 3 provides some statistics on these variables. The main expenditures incurred to run a WWTP are depreciation, energy, and sludge disposal. This evidence shows that the wastewater treatment is a capital intensive activity, since the staff costs incurred are, on average, about $8 \%$. The ranking of cost items is quite similar among plants of different size, even if the percentage of depreciation is higher in WWTPs of small and medium size, while for large plants, energy is the highest expenditure.

\section{Table 3}

Statistical features for input and output variables.

\begin{tabular}{|c|c|c|c|c|c|}
\hline Costs in euros & Mean & Percentage & $\operatorname{Max}$ & Min & St. Dev. \\
\hline Reagents & 4,410 & $3.80 \%$ & 219,959 & - & 21,789 \\
\hline Energy & 32,296 & $27.60 \%$ & 492,139 & - & 73,633 \\
\hline Staff & 9,506 & $8.10 \%$ & 114,360 & - & 18,079 \\
\hline Maintenance & 388 & $0.30 \%$ & 30,559 & - & 2,665 \\
\hline Depreciation & 40,435 & $34.60 \%$ & 798,371 & 15 & 96,525 \\
\hline Sludge disposal & 25,327 & $21.70 \%$ & 360,108 & - & 56,764 \\
\hline Other waste disposal & 3,631 & $3.10 \%$ & 160,213 & - & 17,085 \\
\hline General costs & 828 & $0.70 \%$ & 15,910 & - & 2,094 \\
\hline
\end{tabular}




\begin{tabular}{l|llllr} 
Total costs & 116,822 & $100 \%$ & $1,874,001$ & 79 & 253,010 \\
WW treated & 380,560 & & $6,884,805$ & 1,317 & $1,014,699$
\end{tabular}

The set of operational variables was defined considering these issues: 1) wastewater features, 2) WWTP technology, 3) other features of WWTPs, 4) output quality, and 5) methods of sludge disposal. Points 4) and 5) have not been studied before, while points 1) and 2) were enriched with more variables that could potentially affect the plant's efficiency (Davies, 2005), as the percentage of wastewater from non-domestic customers, the ratio between different pollutants dissolved in wastewater inflow, and the plant's working capacity.

The following wastewater features were included: wastewater from non-domestic customers, percent dilution of wastewater inflow, average concentration of BOD5, ratio of BOD5 to $\mathrm{N}$ concentration, and ratio of COD to BOD5 concentration. The WWTP technologies considered in this article are: type of aeration system (punctual/widespread) and presence of sludge treatment on site (Yes/No). Among the other WWTP features, three variables were observed: plant capacity (PE), year of building, and percent of production capacity used. The output quality is measured as the percentage of controls not compliant with environmental standards provided by law. Finally, the method used for sludge disposal was observed, measuring the percentage of sludge disposed in agriculture.

The 12 operational variables mentioned in Table 4 were measured for year 2014; then, applying the conditional order-m efficiency, they were strictly related to WWTP efficiency in order to explain the variations among different plants and to identify the main drivers.

\section{Table 4}

Measures for exogenous variables.

\begin{tabular}{ll}
\hline \multicolumn{1}{c}{ Operational variables } & \\
\hline \multicolumn{1}{c}{ Wastewater features } & \\
WW from non-domestic customers & $\mathrm{m}^{3}$ of WW from non-domestic customer/total $\mathrm{m}^{3}$ of inflow \\
Dilution of WW inflow & $\mathrm{m}^{3}$ of WW treated/estimated $\mathrm{m}^{3}$ of WW in dry weather \\
Average concentration of BOD5 & gr. of BOD5 per $\mathrm{m}^{3}$ of $\mathrm{WW}$ treated \\
Ratio of BOD5 to N concentration & gr. of BOD5 to gr. of $\mathrm{N}$ per $\mathrm{m}^{3}$ of $\mathrm{WW}$ treated \\
\hline
\end{tabular}




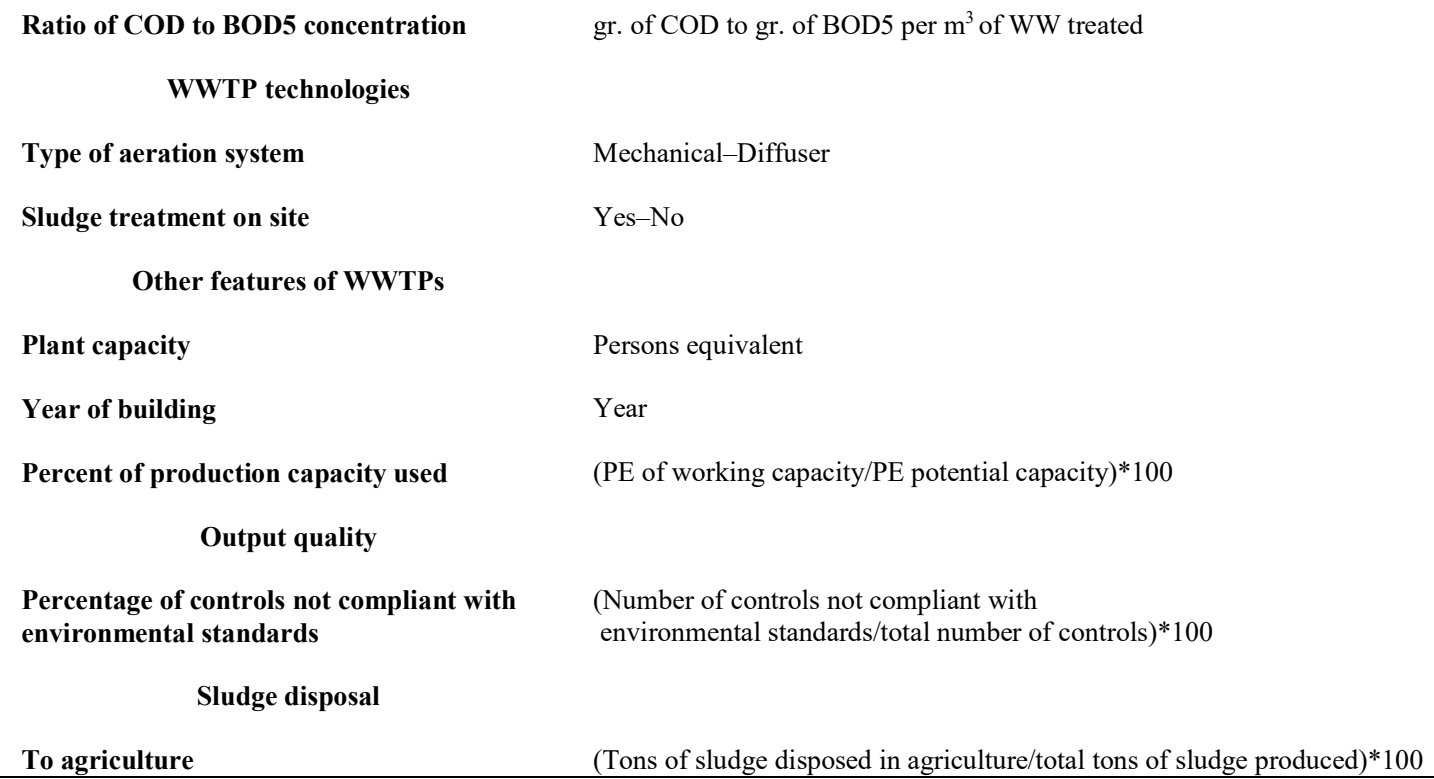

The 137 selected plants show different characteristics for every exogenous variable observed (Table 5). With reference to the wastewater features, the dilution and the pollutant concentration vary widely, as well as the share of wastewater coming from non-domestic customers such as factories and farms. The ratio of BOD5 to $\mathrm{N}$ varies from 10 to 0.25 , with a minimum value much lower than the value given by the technical literature (100 parts of BOD5 for 19 of $\mathrm{N}$ ). The ratio of COD to BOD5 is 3.10, and is over the standard of 2 provided by the literature (Davies, 2005). Considering the plant capacity, there is great variation between the largest and smallest plants, at 90,000 and 50 PE, respectively. This variable is important because Directive 91/271/EEC relative to urban wastewater treatment sets obligations to municipalities regarding the coverage rate of these services, measured in terms of PE.

The plant capacity is on average widely used, with a mean value of 95\%; however, there are some extreme observations with a low degree of used capacity (9\%) and with an amount of work much greater than the plant capacity (281\%). Considering the remaining features of WWTPs, the secondary treatment with activated sludge and diffusors for aeration is the technology adopted more frequently by Acque SpA. Sludge treatment is usually carried out on site, and the disposal is made to composting plants, and then to farms (see Table 6).

\section{Table 5}


Statistical features of the operational variables.

\begin{tabular}{|c|c|c|c|c|}
\hline & Mean & $\operatorname{Max}$ & Min & St. Dev. \\
\hline WW from non-domestic customers & 0.03 & 0.75 & 0 & 0.1 \\
\hline Dilution of $W W$ & 4.26 & 68.81 & 0.16 & 7.27 \\
\hline BOD5 concentration $(\mathrm{gr} / \mathrm{mc})$ & 173.82 & 875 & 3 & 137.89 \\
\hline BOD $5 / N$ & 2.94 & 10.86 & 0.25 & 1.52 \\
\hline COD/BOD5 & 3.1 & 14.09 & 1.96 & 1.37 \\
\hline Plant capacity & 5,153 & 90,000 & 50 & 13,602 \\
\hline \multirow{2}{*}{$\begin{array}{c}\text { Year of building } \\
\text { percentage of working capacity }\end{array}$} & 1988 & 2009 & 1962 & 9 \\
\hline & $95 \%$ & $281 \%$ & $9 \%$ & $46 \%$ \\
\hline percentage of non-compliant controls & $1.00 \%$ & $10.10 \%$ & $0.00 \%$ & $2.20 \%$ \\
\hline percentage of sludge to farms & $3.80 \%$ & $44.90 \%$ & $0.00 \%$ & $9.80 \%$ \\
\hline
\end{tabular}

\section{Table 6}

WWTP technologies.

\begin{tabular}{lr}
\hline Type of treatment & Number of plants \\
\hline Primary & 9 \\
Secondary & 126 \\
Ternary & 4 \\
\hline Activated sludge & Number of plants \\
\hline No & 16 \\
Yes & 114 \\
Primary treatment & 9 \\
\hline Type of aeration & \\
\hline Diffuser & Number of plants \\
Mechanical & 88 \\
No aeration & 29 \\
\hline Sludge treatment on site & Number of plants \\
\hline Yes & 118 \\
No & 21 \\
\hline
\end{tabular}


To the best of our knowledge, variables such as "wastewater from non-domestic customers", "percentage of dilution of wastewater inflows", "ratios of pollutants" (BOD5/N and COD/BOD5), "percentage of working capacity", "percentage of non-compliant controls", and "methods of sludge disposal" have never been investigated before, despite their potentially significant effects on the efficiency of water utilities. Similarly, in considering the technology of WWTPs, the effect on costs and efficiency of a sludge treatment plant operating on site has never been examined.

\section{How operational variables affect efficiency}

In the current study, the efficiency drivers are grouped into five main categories: wastewater features, WWTP technology, other features of WWTPs, output quality, and sludge disposal.

The shape reported in the figures of Appendix A shows the results of nonparametric partial regression for the conditional efficiency to unconditional efficiency ratios with the contextual variables. According to Cazals et al. (2002), the m value was kept when the reduction of the number of DMUs below the frontier remains stable $(\mathrm{m}=40)$.

With the input orientation, a positive slope indicates a negative effect of the operational variable on efficiency, and vice versa.

Beginning with the first cluster, sewage from non-domestic customers weakly decreases efficiency to 0.15 ; then, this negative effect is improved to 0.22 , so that an increase in industrial wastewater increases costs; while beyond the upper threshold, efficiency increases. This occurred with a 5\% significance level (the region between the grey lines in Figure A.1 of Appendix A and in the following figures corresponds to a $95 \%$ confidence level of nonparametric regression). For the majority of DMUs, distributed between 0 and 0.15 , the observed operational variable negatively affected performance: this can be explained by considering the higher quantity and quality of reagents consumed and the more innovative technologies adopted to treat industrial wastewater. Furthermore, high concentrations of toxic chemicals dissolved in sewage from manufacturing industries can kill 
bacteria: if this shock occurs, the plant discharges effluent to the environment, and the activated sludge must be renewed, incurring higher costs.

The observed dilution of wastewater for the population is on average concentrated between zero and five; within this interval, efficiency increases when wastewater is more diluted, since a highly loaded organic wastewater will ultimately lead to higher energy cost for aeration needs and generate higher sludge production rates. When the ratio of wastewater inflow to wastewater expected in dry seasons is greater than 5 , the efficiency is negatively related to dilution. The latter result is quite intuitive, since the treatment of a cubic meter of wastewater that is too diluted generates much waste in terms of energy, and can cause operational problems such as a low sludge settling index or low organic removal rates. (Figure A.2). This implies that Acque SpA and local water authorities should consider investing in a new sewer network that keeps sewer and storm water separate.

The global concentration of BOD5 exerts a negative influence on efficiency, starting from $0 \mathrm{gr} / \mathrm{m}^{3}$ to $500 \mathrm{gr} / \mathrm{m}^{3}$. Examining in more detail the slope of Figure A.3, we see that the efficiency varies positively when the BOD5 concentration increases within the width between 0 and about $200 \mathrm{gr} / \mathrm{m}^{3}$; then it declines. These results imply that after a certain threshold, a large amount of BOD5 per cubic meter of wastewater inflow makes the treatment process more onerous, especially for the large amount of sludge produced. Alternatively, the positive effect of BOD5 concentration recorded within the lower width $\left(0-200 \mathrm{gr} / \mathrm{m}^{3}\right)$ could be explained by considering that carbon is a nutrient for microorganisms (bacteria, protozoa, and microbes) living in the plant's activated sludge, and its consumption allows the transformation of other pollutants, such as nitrogen, into more degradable components. The results of this study well illustrate the trade-off related to the high BOD5 concentration: this pollutant feeds microorganisms, but at the same time, it contributes to generating sludge through the fast growth of bacteria. The value of $200 \mathrm{gr} / \mathrm{m}^{3}$ represents the cutoff value for the plants observed.

The technical literature provides standard parameters related to the ratios of pollutants. The average carbon to nitrogen to phosphorus ratio $(\mathrm{C} / \mathrm{N} / \mathrm{P}$ ratio) is variously stated as $100: 17: 5$ or 
100:19:6 (Davies, 2005). Thus, the amount of carbon measured in terms of BOD5 should be approximately five times the quantity of nitrogen, which in turn should be four times the quantity of phosphorus. The achievement of this standard is ideal to feed the activated sludge bacteria. Considering the ratio of BOD5 to $\mathrm{N}$, a higher quantity of expected carbon contributes to produce bulking and foaming, with a larger amount of sludge. In contrast, a higher proportion of nitrogen makes it more difficult to transform this pollutant into more degradable elements. The sewage treated by the WWTP of Acque shows a ratio of BOD5 to N lower than the ideal standard. Sewage coming from the brewing and pulp and paper industries are often deficient in nitrogen, so this nutrient needs to be added to allow effective treatment. The slope in Figure A.4 demonstrates that efficiency increases with BOD5/N ratio; however, after six parts of carbon to one of nitrogen, efficiency begins to decrease, since the ideal standard is overrun.

The values of COD are always greater than BOD5, so that activated sludge cannot digest all the compounds that have to be chemically oxidized. As previously mentioned, for domestic sewage, the ratio is around 2. A higher ratio indicates that the wastewater is full of compounds that cannot be easily degraded. The points in Figure A.5 are in great part distributed around 2 and 3.5, so that the average value of the COD/BOD5 ratio for Acque WWTPs is 3.10. The efficiency does not vary until a value of 5 is reached, then it decreases rapidly toward extreme observations, but with a lack of statistical significance. This trend confirms the standards provided by the literature, and sets the value of 5 as an upper limit for COD/BOD5.

The adoption of mechanical aeration results in higher consumption of input per cubic meter than that of plants with diffuser systems (Figure A.6). With mechanical aeration, water is mixed vigorously, allowing air to be introduced, while diffusers are designed to produce bubbles by forcing air into the tanks. This conflicts somewhat with the results of prior studies (Fuentes et al., 2015) that have demonstrated that the type of aeration does not affect efficiency, and also with evidence from Hernández-Sancho et al. (2011a). The latter demonstrates that diffuser plants remove more pollutants per cubic meter of wastewater treated, but they also consume more energy than turbine plants. 
For the largest plants, Acque has opted to vertically integrate the WWTP with the sludge treatment phase, installing on site a plant to obtain dry matter from sludge. This approach should allow economies of scope, reducing the amount of sludge disposal costs. However, observing the selected 137 WWTPs, the strategy to integrate wastewater and sludge treatment reduces the plant's efficiency (Figure A.7), probably because the savings in sludge disposal costs is overwhelmed by the increase of depreciation and energy costs. Among the other features of WWTPs, the plant capacity represents the scale of the operation. Figure A.8 confirms results from prior literature (Hernandez-Sancho et al., 2011; Hernandez-Sancho et al., 2011a; Molinos-Senante et al., 2014a and 2014b), that the plant's size has a positive influence on efficiency, showing that economies of scale affect this segment of wastewater treatment. In the case of Acque WWTPs, efficiency increases when plant capacity passes from 50 to approximately 12/13,000 PE. Beyond this threshold, there is no statistical significance in local polynomial smoothing (Figure A.8).

The plant's age has two main effects on costs: 1) increased maintenance costs to prevent machinery breakdown; 2) older plants often perform only the primary treatment, without an aeration system, so their energy consumption is lower than that of new plants. The slope in Figure A.9 shows that the latter effect prevails on the former, since the efficiency drops when the building is more recently established. This evidence conflicts with the result of Molinos-Senante et al. (2014b), which indicates that older plants are less efficient than younger ones.

One way to boost efficiency is to operate at a large scale, but also assuring a high used capacity rate, in order to shrink fixed costs per cubic meter of treated wastewater. Acque SpA owns plants with working capacities ranging from $9 \%$ to $281 \%$ of potential capacity. Efficiency improves when the weight of working capacity grows to $130 \%-140 \%$ : when the percentage of used capacity exceeds this value, the plant faces the risk of reduced efficiency and problems occurring during the treatment process (Figure A.10).

The output quality was measured via the number of controls that are not compliant with the standards for effluent emission authorized by law. A high rate of non-compliant controls may be 
associated with poor treatment quality and, at the same time, to a low amount of resources invested in the process. This implies that when the quality decreases, the efficiency increases; this trend occurs until non-compliant controls reach a weight of 0.65 , after which the inefficiency increases (Figure A.11).

The last operational variable studied here is the chosen method of sludge disposal. According to the management of Acque, the best destination for sludge is agriculture, followed by composting plants, landfills, and incineration. This expectation is fully met if the slope in Figure A.12 is observed; with the exception of some extreme observations, a larger amount of sludge disposed to farms improves efficiency. A summary of the obtained results are shown in Figure 1.

Figure 1. Summary of results obtained in this study

\begin{tabular}{|c|c|c|c|c|}
\hline $\begin{array}{l}\text { WASTEWATER } \\
\text { FEATURES }\end{array}$ & \begin{tabular}{|l|} 
WWTPS \\
TECHNOLOGY
\end{tabular} & $\begin{array}{l}\text { OTHER } \\
\text { FEATURES }\end{array}$ & $\begin{array}{l}\text { OUPTUT } \\
\text { VARIABLES }\end{array}$ & \begin{tabular}{|l} 
SLUDGE \\
DISPOSAL
\end{tabular} \\
\hline $\begin{array}{l}\text { - BOD } 5 \text { concentration } \\
\text { can grow to } 200 \mathrm{gr} / \mathrm{M}^{3} \\
\cdot \text { COD } / \text { BOD } 5 \text { and } \\
\text { BOD } / \mathrm{N} \text { cause a } \\
\text { decrease of efficiency } \\
\text { when values reach }>5 \\
\text { and }>6, \text { respectively. } \\
\text {-A high } \% \text { of WW from } \\
\text { non-domestic } \\
\text { customers decreases } \\
\text { efficiency } \\
\text {-A high dilution of } \\
\text { WW inflow decreases }\end{array}$ & $\begin{array}{l}\text { A vertical integration } \\
\text { strategy, aiming to } \\
\text { integrate wastewater } \\
\text { and sludge } \\
\text { treatment activities } \\
\text { negatively affect cost } \\
\text { efficiency. } \\
\text { - A mechanical } \\
\text { aeration is more } \\
\text { expensive than } \\
\text { diffusers }\end{array}$ & $\begin{array}{l}\text { - When plant capacity } \\
\text { increases, efficiency } \\
\text { is improved. } \\
\text { - The building age } \\
\text { positively influences } \\
\text { efficiency } \\
\text { - Cost savings are } \\
\text { obtained when the } \\
\text { weight of working } \\
\text { capacity increases up } \\
\text { to } 130 \%-140 \%\end{array}$ & $\begin{array}{l}\text { Efficiency increases } \\
\text { until } 6 / 7 \% \text { of non- } \\
\text { compliant controls is } \\
\text { reached }\end{array}$ & $\begin{array}{l}\text { Efficiency increases } \\
\text { when the sludge } \\
\text { diposed in farms } \\
\text { rises from } 13 \% \text { to } \\
38 \%\end{array}$ \\
\hline
\end{tabular}

\section{Conclusions}

An efficient wastewater treatment service is essential to a good standard of living for citizens. In European countries, this service is often provided by utilities, which have to comply with environmental laws on discharging treated water to rivers, oceans, or groundwater aquifers; at the 
same time, they must control the costs of the treatment process, in order to restrain tariff growth. This study provides some insights on the operational variables that should be constantly monitored by the plant manager, because they exert an influence on efficiency trends. Since the variables observed are only partially controllable by a plant's manager, the main actions suggested by this paper for efficiency improvements are: 1) activate an effective control system for each plant in order to verify if the achievement of target values for some variables, such as wastewater pollutants load and used plant capacity; 2) consider the effects exerted by performance drivers in the design phase of new plants. The factors studied are grouped as follows: 1) wastewater features, 2) WWTP technology, 3) other features of WWTPs, 4) output quality, and 5) method of sludge disposal. Wastewater features are not controllable by a plant manager, but their values should trigger a reaction to set the treatment process for achieving a low level of effluent discharge, thereby restraining costs. Thus, a variation of BOD5-to-N ratio greater than 5 indicates that some chemical elements (e.g., urea) must be added to the sewage, in order to rebalance the ratio, or alternatively, two wastewaters with different features can be mixed (e.g., industrial wastewater with low $\mathrm{N}$ content, and civil wastewater). Then, if the value of COD/BOD5 does not meet the standard provided by scientific literature, the plant manager usually adds carbon elements to the sewage or activates further chemical treatments. However, all these alternatives generate more cost per cubic meter of wastewater treated, and increases inefficiency. Similar implications are derived from evidence concerning BOD5 and N concentrations. This paper helps plant managers to set the correct target for every measure, in order to properly develop the wastewater treatment process.

The performance of WWTPs may also differ according to the technology implemented, and to other plant features, such as age, size, and rate of working capacity. Evidence from this study indicates that before choosing to invest in a new technology or to buy a new plant, the real benefits and cost of this choice must be accurately evaluated. Furthermore, when building a new WWTP, its size must be well matched to the size of the area served, in terms of inhabitants and tourist flows, keeping in mind that small plants and those with a used capacity rate that is too high or too low perform badly. For 
these variables, this paper also shows the target value that should be achieved to assure efficiency improvements. Our results on the output quality generate some concern on the regulatory model for wastewater services: the faculty given to some plants by law 152/2006 to not comply with environmental standards provide an advantage to these "poor performers", that collect the same tariff as others, but incur lower costs. This highlights the unfair competition that should be addressed by national and local regulators. Finally, among the different alternatives for sludge disposal, the benefits arising from discharge to agriculture should induce plant managers to increase the weight of this destination, for example by arranging agreements with associations of farmers to raise the quantity of sludge disposed.

The current study is not without limitations. A first limitation concerns the data collected, which are all referred to only one year. In this respect, future research should focus on calculating efficiency over time, comparing changes, and observing trends for homogenous groups of WWTPs, in terms of technology adopted and scale of operations.

Secondly, a multivariate kernel function should be adopted to estimate the effect exerted by continuous and discrete environmental variables on efficiency, according to the procedure proposed by De Witte and Kortelainen (2013). A multivariate approach could better represent the behavior of environmental variables, which do not act in an isolated way.

Then, a more robust procedure to test the significance of the results achieved should be applied, following, for example, the work of Ferreira and Marques (2015), which adopted a conditional and non-conditional subsampling bootstrap-based methodology.

Finally, in order to identify separately the effect of $Z$ on the shift of the frontier and on the distribution of inefficiency, the method proposed by Badin et al. (2012) could be applied, which is based on the analysis of different curves obtained with a decreasing sequence of $\alpha$. Thus, a full frontier conditional to unconditional efficiency ratio is useful to investigate the effect of $Z$ on the shift of the frontier; while a partial frontier ratio (with $\alpha=0.5$ ) can be estimated to investigate the effect of $\mathrm{Z}$ on the distribution of inefficiency. 


\section{Acknowledgements}

This research was partially supported by the University of Pisa (PRA 2016 Project) and EACEA (Erasmus + Jean Monnet Module European Water Utility Management (EWUM, project 2014-1288).

The authors would like to thank the Acque SpA and Ingegnerie Toscane Srl for their precious help in collecting data, and participants of the International Seminar on "European Water Utility Management: Promoting Innovation within the Water Industry and Spreading Knowledge on Relevant and Cutting Edge Water Utility Issues" held in Pisa June 3, 2015, who provided insight and expertise that greatly assisted this research.

\section{Appendix A.}

\section{Conditional order-m analysis}

Figure A.1. Wastewater from non-domestic customers

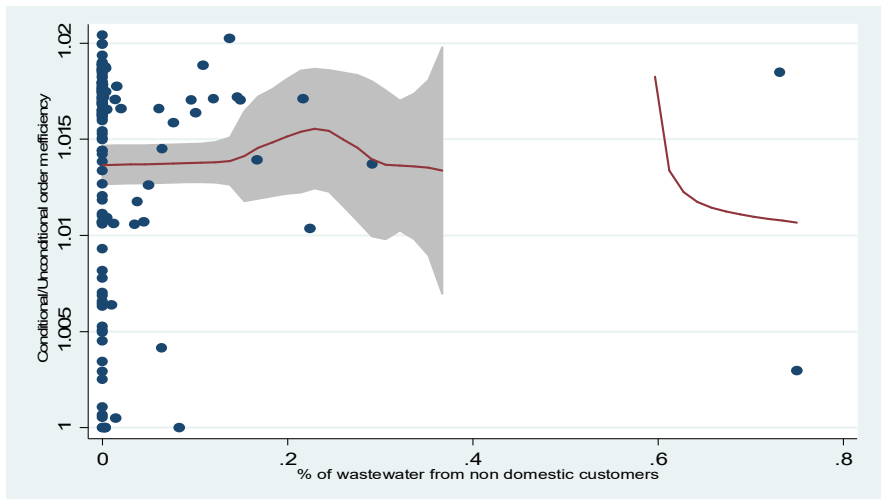

Figure A.2. Dilution of wastewater inflow 


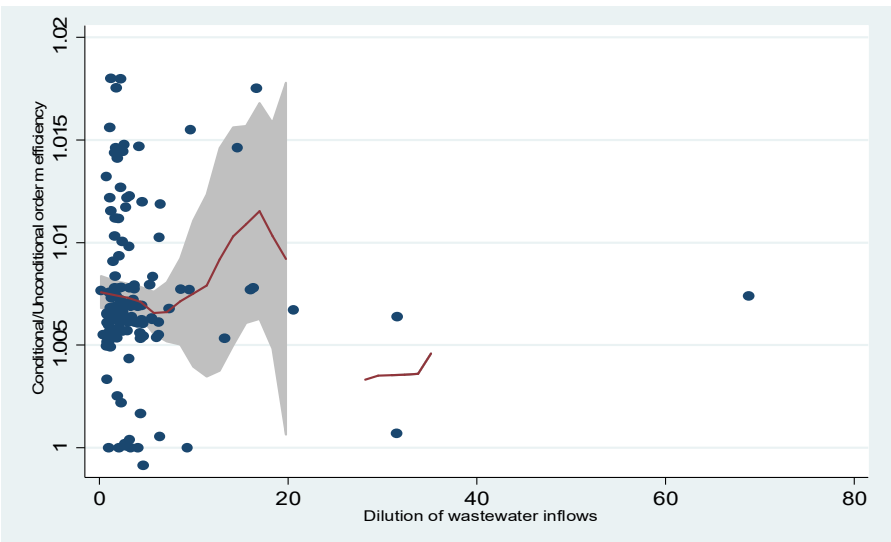

Figure A.3. Average concentration of BOD5 in water inflow

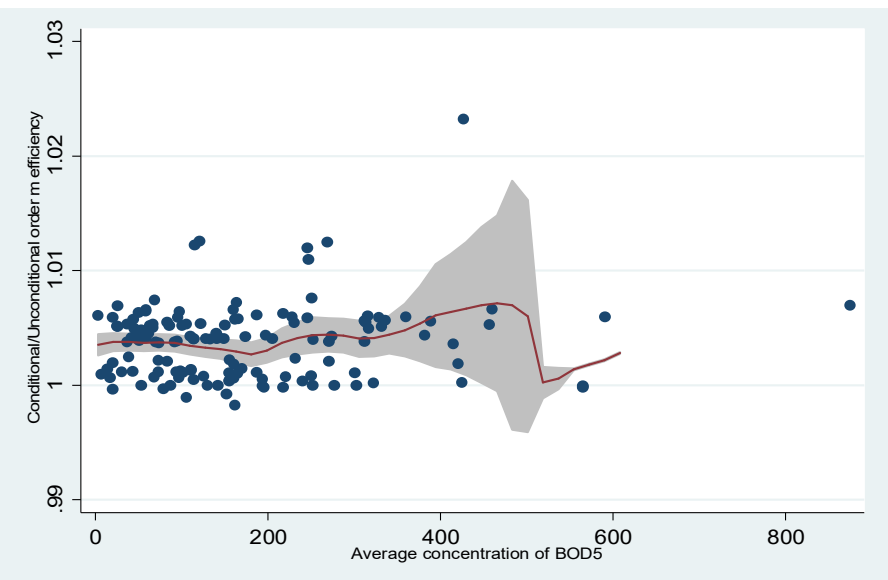

Figure A.4. Ratio of BOD5 to Nitrogen concentration

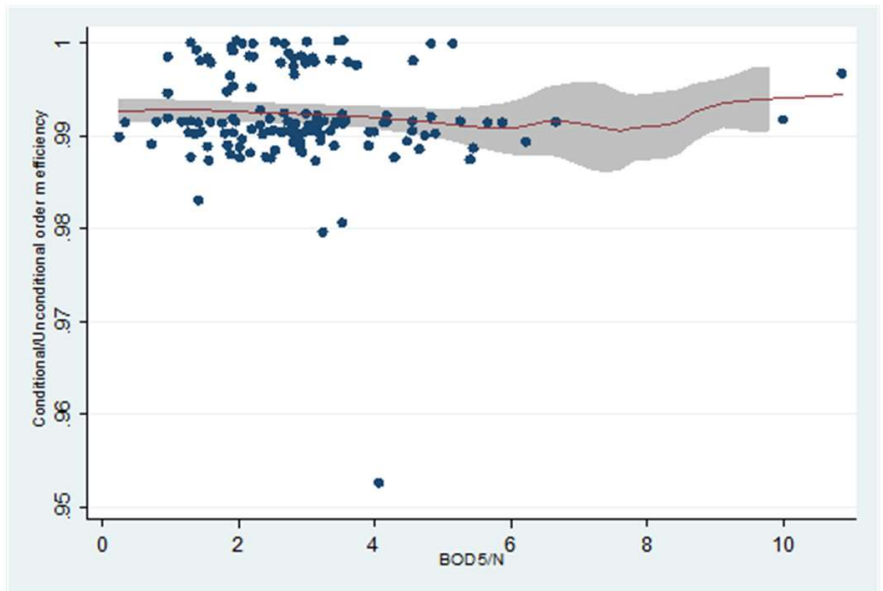

Figure A.5. Ratio of COD to BOD5 concentration 


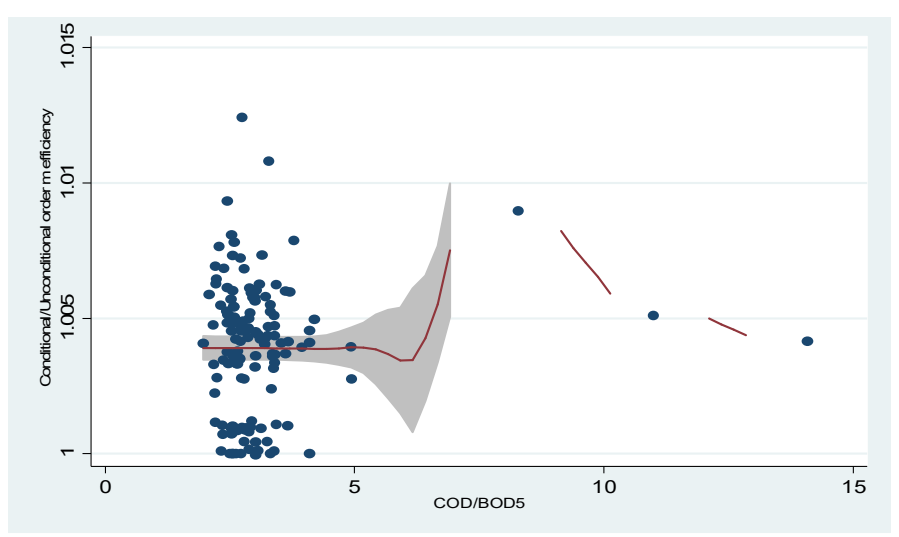

Figure A.6. Aeration system (0: diffusers; 1: turbines; 2: no aeration)

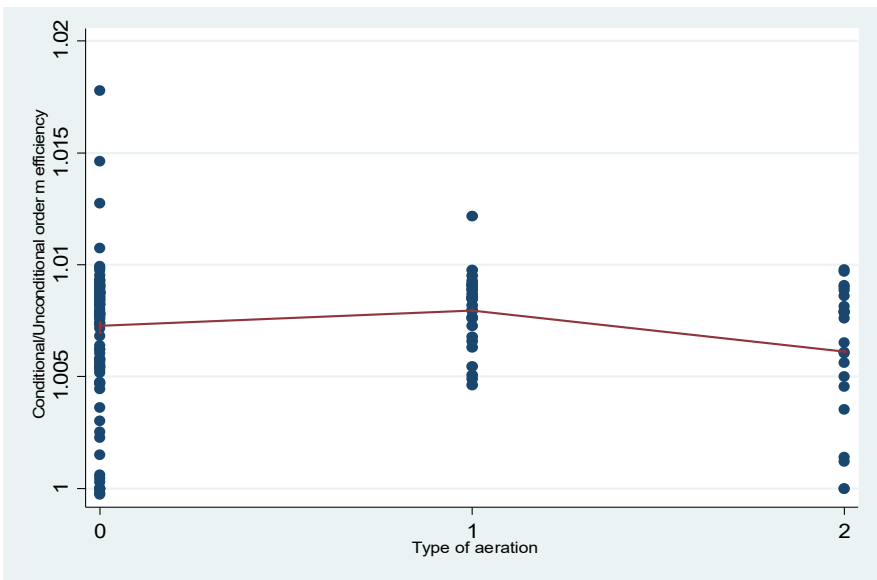

Figure A.7. Sludge treatment (0: NO; 1: YES)

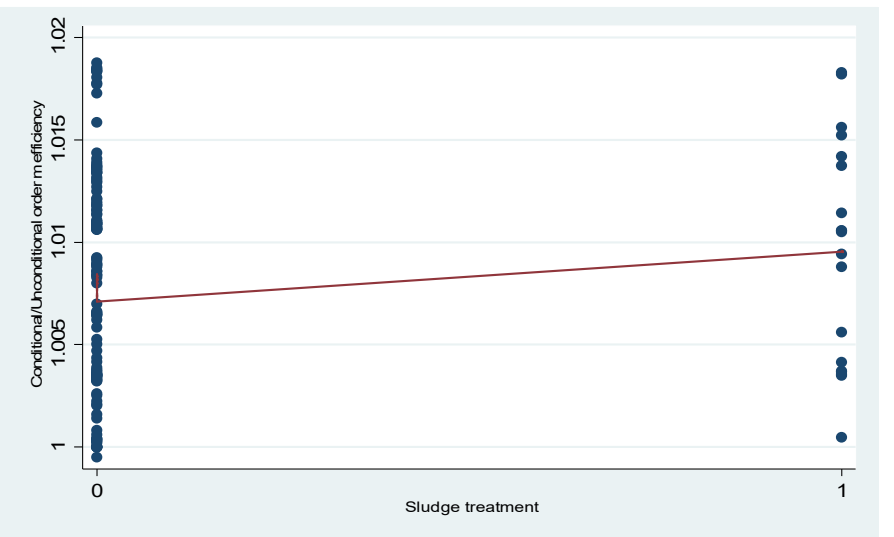

Figure A.8. Plant capacity 


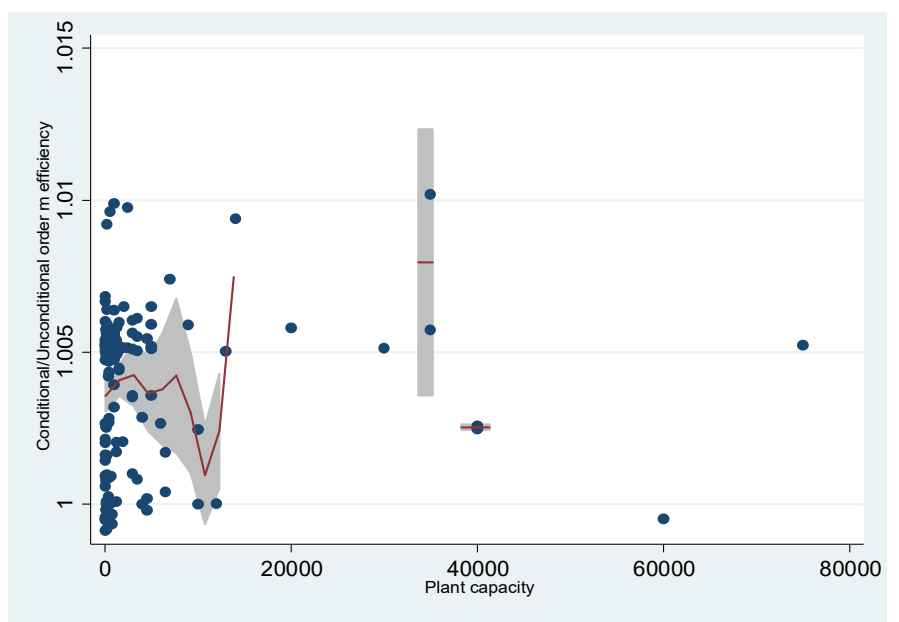

Figure A.9 Year of building

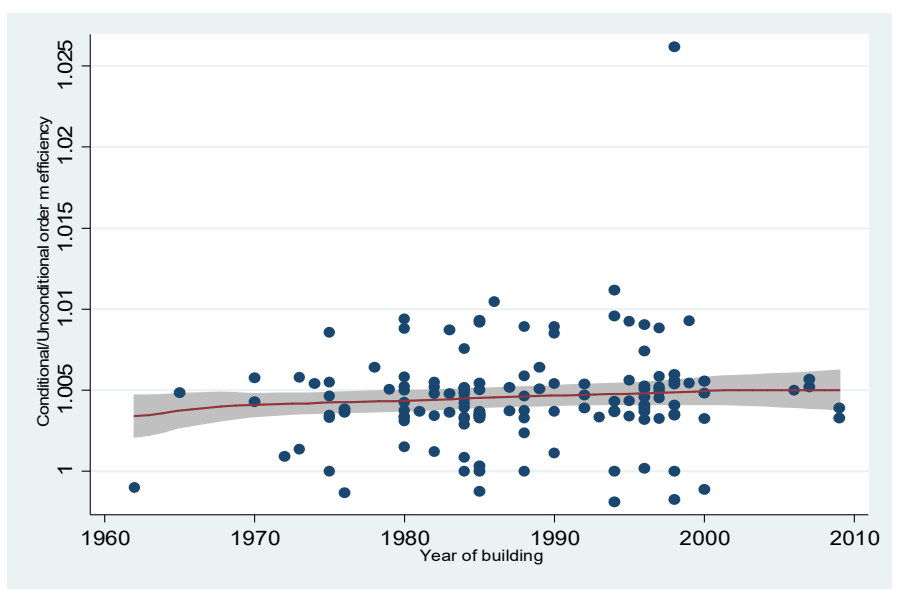

Figure A.10. Persons Equivalent working capacity/Persons Equivalent potential capacity

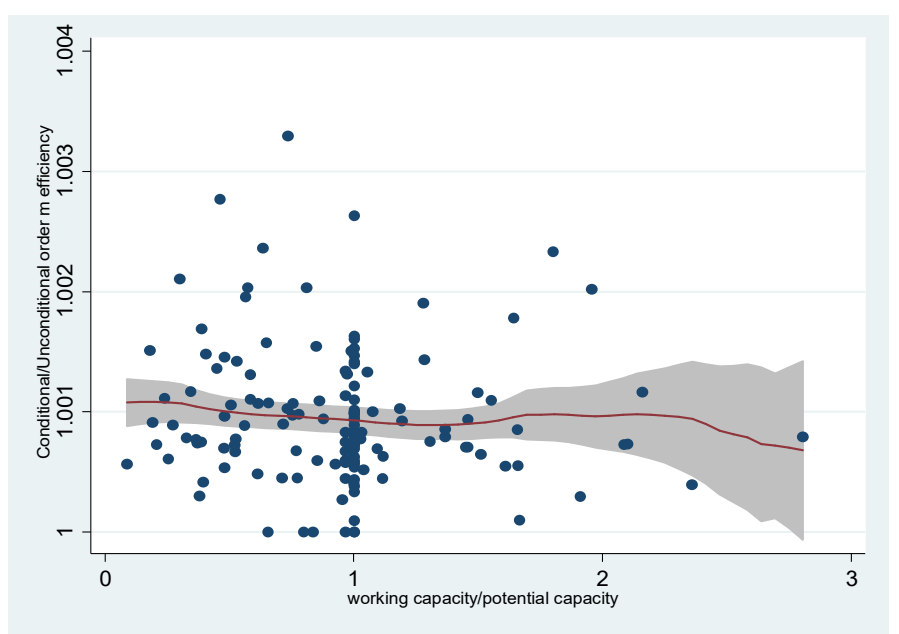

Figure A.11 Incidence of controls not compliant with environmental standards 


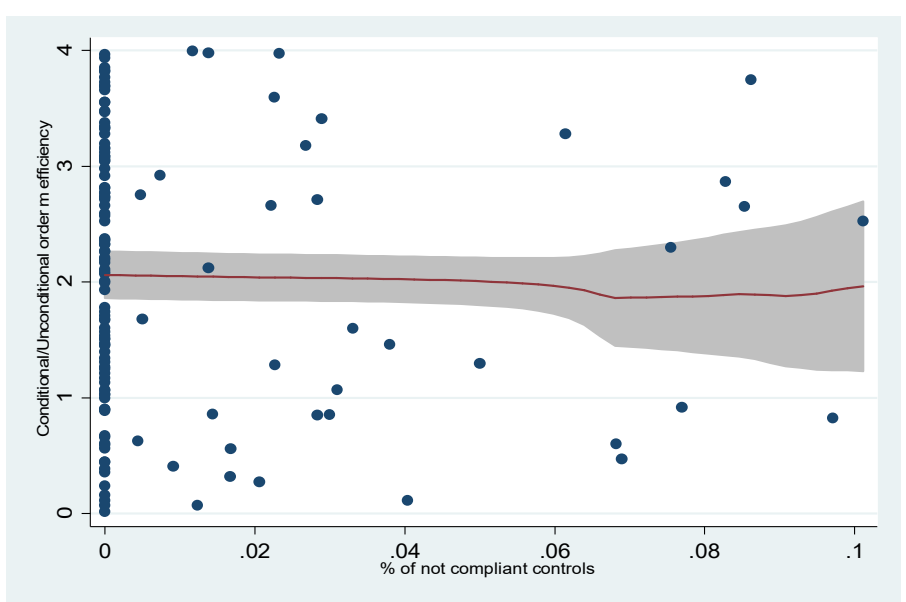

Figure A.12 Incidence of sludge disposed in farms on total sludge produced

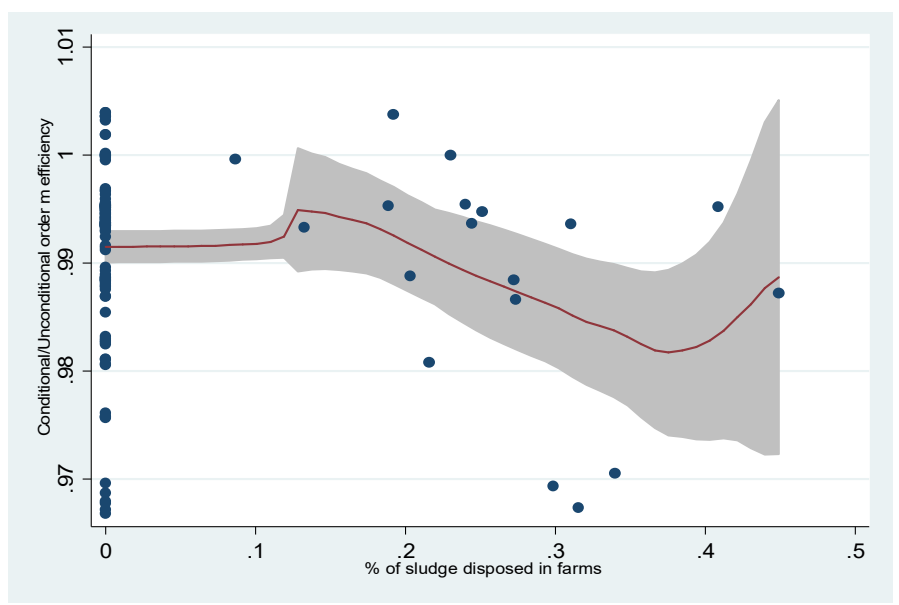

\section{References}

Abbott M., Chun, W.W., Cohen, B., 2011. The long-term reform of the water and wastewater industry: The case of Melbourne in Australia. Util. Policy 19, 115-122.

Ashton, S.K., 2000. Cost efficiency in the U.K. water and sewerage industry. Appl. Econ. Lett. 7, 455-458.

Badin, L., Daraio, C., Simar, L., 2010. Optimal bandwidth selection for conditional efficiency measures: A data-driven approach. Eur. J. Oper. Res. 201, 633-640.

Badin, L., Daraio, C., Simar, L., 2012. How to measure the impact of environmental factors in a nonparametric production model. Eur. J. Oper. Res. 223, 818-833.

Badin, L., Daraio, C., Simar, L., 2014. Explaining inefficiency in nonparametric production models: the state of the art. Ann. Oper. Res. 214, 5-30. 
BDEW, 2010, VEWA comparison of European Water and Wastewater prices, available at https://www.bdew.de/internet.nsf/id/DE_VEWA-

Survey_summery_Comparison_of_European_Water_and_Wastewater_Prices/\$file/_12_seiter_ vewa_studie_bdew_ENGL_V2.pdf

Bonomo, L. 2008 Trattamenti delle Acque Reflue. McGraw Hill Education, Milano.

Cazals, C., J. Florens, Simar L., 2002. Nonparametric frontier estimation: A robust approach. J. Econom. 106, 1-25.

da Cruz, N.F., Carvalho, P., Marques, R.C., 2013. Disentangling the cost efficiency of jointly provided water and wastewater services. Util. Policy 24, 70-77.

da Cruz, N., Marques, R., Romano, G., Guerrini, A., 2012. Measuring the efficiency of water utilities: A cross-national comparison between Portugal and Italy. Water Policy 14, 841-853.

Danva Report, 2013. Water in Figures DANVA benchmarking 2013: process benchmarking and statistics", available at http://www.e-pages.dk/danva/132/18

Daraio, C., Simar, L., 2005. Introducing environmental variables in nonparametric frontier models: A probabilistic approach. J. Product. Anal. 24, 93-121.

Daraio, C., Simar, L., 2007. Advanced Robust and Nonparametric Methods in Efficiency Analysis: Methodology and Applications. Springer, New York.

Davies, P., (2005). The Biological Basis of Wastewater Treatment. Strathkelvin Instruments Ltd.

De Witte, K., Kortelainen, M., 2013. What explains the performance of students in a heterogeneous environment? Conditional efficiency estimation with continuous and discrete environmental variables. Appl. Econ. 45(17), 2401-2412.

De Witte, K., Marques, R., 2012. Gaming in a benchmarking environment. A non-parametric analysis of benchmarking in the water sector. Water Policy 14, 45-66.

Eurostat, 2013. Environmental protection expenditure. http://epp.eurostat.ec.europa.eu/ statistics_explained/index.php/Environmental_protection_expenditure. Accessed June 31, 2016

Federconsumatori, 2014. XIII indagine nazionale a campione sulle tariffe 2013 del servizio idrico integrato, available at 
http://www.federconsumatori.it/news/foto/Indagine\%20nazionale\%20tariffe\%20SII\%202013_1

1maggio14.pdf

Ferreira, D., Marques, R.C., 2015. Did the corporatization of Portuguese hospitals significantly change their productivity? Eur. J. Health Econ. 16(3), 289-303.

Fraquelli, G., Giandrone, R., 2003. Reforming the wastewater treatment sector in Italy: Implications of plant size, structure, and scale economies. Water Resour. Res. doi:10.1029/2003WR002037

Fuentes, R., Torregrosa, T., Ballenilla, T., 2015. Conditional Order-m Efficiency of Wastewater Treatment Plants: The Role of Environmental Factors. Water 7.10, 5503-5524.

Guerrini, A., Romano, G., 2014. Water Management in Italy. Governance, Performance and Sustainability. Springer, Frankfurt.

Guerrini, A., Romano, G., Campedelli, B., 2013. Economies of scale, scope, and density in the Italian water sector: A two-stage data envelopment analysis approach. Water. Resour. Manag. 27, 45594578.

Guerrini, A., Romano, G., Leardini, C., Martini, M., 2015. The effects of operational environmental variables on efficiency of Danish water and wastewater utilities. Water 7, 3263-3282.

Hernández-Sancho, F., Molinos-Senante, M., Sala-Garrido, R., 2011a. Energy efficiency in Spanish wastewater treatment plants: A non-radial DEA approach. Sci. Total Environ. 409, 2693-2699.

Hernández-Sancho, F., Molinos-Senante, M., Sala-Garrido, R., 2011b. Techno-economical efficiency and productivity change of wastewater treatment plants: The role of internal and external factors. J. Environ. Monit. 1, 3448-3459.

Hernández-Sancho, F., Sala-Garrido, R., 2009. Technical efficiency and cost analysis in wastewater treatment processes: A DEA approach. Desalination 249, 230-234.

Hsiao, C.K., Yang, C.C., Bjornlund, H., 2007. Performance measurement in wastewater control. Pig farms in Taiwan. WIT Trans. Ecol. Environ. I, 467-474.

Knapp, M., 1978. Economies of scale in sewerage purification and disposal. J. Industrial Econ. 27, $163-183$. 
Lorenzo-Toja, Y., Vázquez-Rowe, I., Chenel, S., Marín-Navarro, D., Moreira, M.T., Feijoo, G., 2015. Eco-efficiency analysis of Spanish WWTPs using the LCA+ DEA method. Water Res. 68, 651666.

Masotti, L. 2011. Depurazione delle Acque. Tecniche ed impianti per il trattamento delle acque di rifiuto. Calderini, Bologna.

Metcalf \& Eddy, Tchobanoglous G, Burton FL, Stensel HD (2003) Wastewater Engineering, Treatment and Reuse, 4th Ed., McGraw Hill Education, New York.

Molinos-Senante, M., Hernandez-Sancho, F., Sala-Garrido, R., 2014. Benchmarking in wastewater treatment plants: a tool to save operational costs. Clean Technol. Environ. Policy 16, 149-161. doi 10.1007/s10098-013-0612-8

Molinos-Senante, M., Hernandez-Sancho, F., Sala-Garrido, R., 2015. Comparing the dynamic performance of wastewater treatment systems: A metafrontier Malmquist productivity index approach. J. Environ. Manage. 161, 309-316.

Molinos-Senante, M., Hernández-Sancho, F., Mocholí-Arce, M., Sala-Garrido, R., 2014a. Economic and environmental performance of wastewater treatment plants: Potential reductions in greenhouse gases emissions. Resour. Energy Econ. 38, 125-140.

Peda, P., Grossi, G., Liik, M., 2013. Do ownership and size affect the performance of water utilities? Evidence from Estonian municipalities. Journal of Management \& Governance 17, 237-259. Picazo-Tadeo A.J., Sàez-Fernàndez F.J., Gonzàlez-Gòmez F., 2009. "The role of environmental factors in water utilities' technical efficiency. Empirical evidence from Spanish companies”, Appl. Econ. 41, pp. 615-628

Portela, M.A., 2014. Value and quantity data in economic and technical efficiency measurement. Economics Letters 124, 108-112.

Racine J.S., Li, Q., (2004). Nonparametric Estimation of Regression Functions with Both Categorical and Continuous Data. J. Econometrics 119(1), 99-130.

Romano, G., Guerrini, A., 2011. Measuring and comparing the efficiency of water utility companies: a data envelopment analysis approach. Util. Policy 19, 202-209.

Rossi, D., Young, C.E., Epp, D.I., 1979. The cost impact of joint treatment of domestic and poultry processing wastewater. Land Economics 55, 444-459. 
Saal, D.S., Parker, D., 2001. Productivity and price performance in the privatized water and sewerage companies of England and Wales. J. Regul. Econ. 20, 61-90.

Sala-Garrido, R., Molinos-Senante, M., Hernandez-Sancho, F., 2011. Comparing the efficiency of wastewater treatment technologies through a DEA metafrontier model. Chem. Eng. J. 173, 766772.

Sala-Garrido, R., Molinos-Senante, M., Hernández-Sancho, F., 2012. How does seasonality affect water reuse possibilities? An efficiency and cost analysis. Resour., Conserv. Recycl. 58, 125-131.

Simar, L., Wilson, P.W., 2004. Performance of the bootstrap for DEA estimators and iterating the principle, in: Cooper, W.W., Seiford, L.M., Zhu, J. (Eds.), Handbook on Data Envelopment Analysis. Kluwer Academic Publishers, Boston, pp. 265-298.

Simar, L., Wilson, P.W., 2007. Estimation and inference in two-stage semi-parametric models of production processes. J. Econometrics 136, 31-64. 